\title{
LEADERS IN RURAL DEVELOPMENT STRUCTURES (CASE STUDY ON THE TERRITORY OF THE LAG DOLNÍ MORAVA, MORAVIA)
}

\author{
Anna Bábíková ${ }^{1}$
}

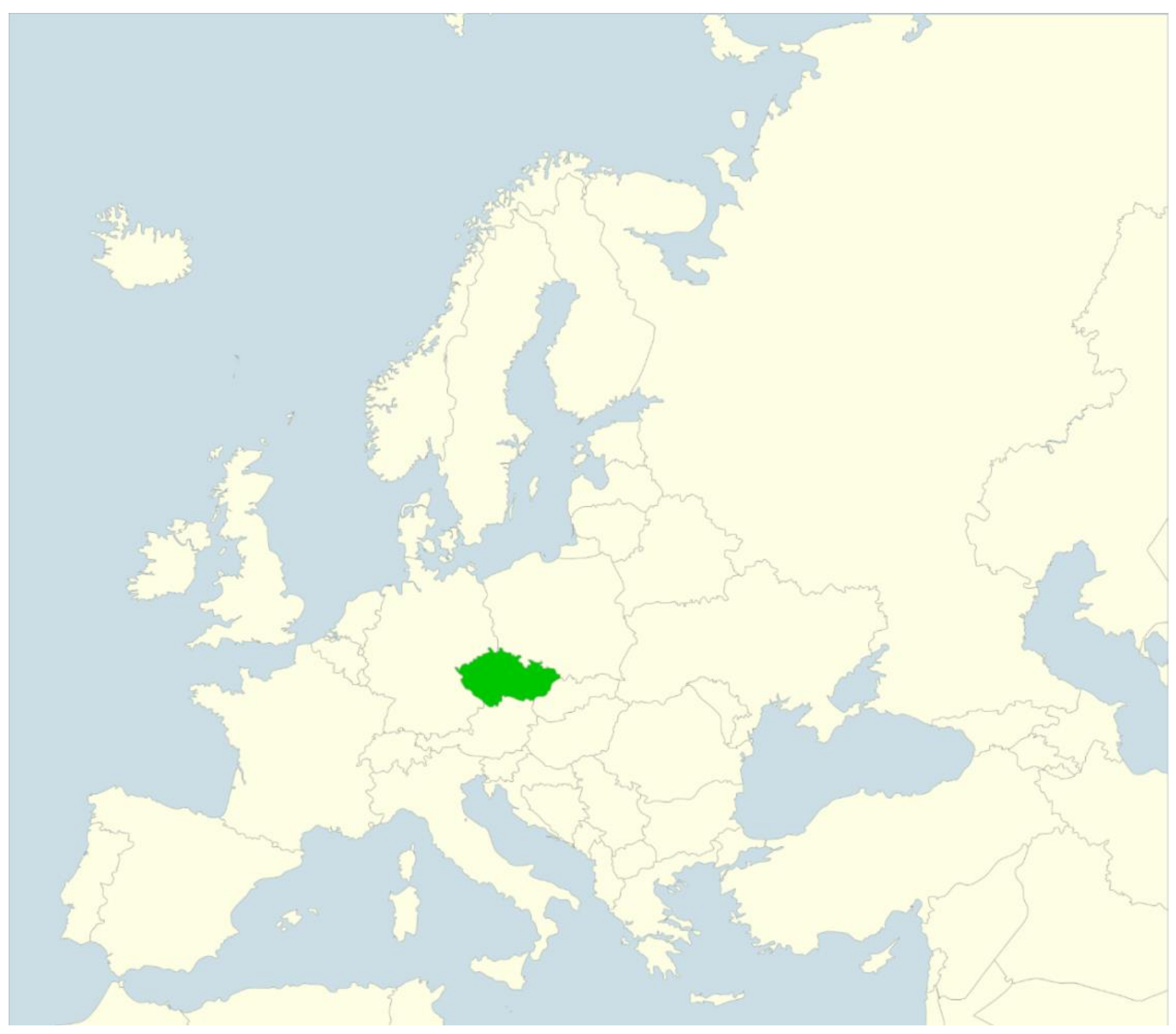




\begin{abstract}
This paper is focused on local actors who are actively involved in the development of their villages. The area of rural development involves stakeholders of different levels and various positions. However, their roles differ, as do their positions in networks collaborating in the development of the rural community. In order to carry out this research, active citizens in member municipalities of the Dolní Morava Local Action Group (covering the territory of the South Moravian Region in the Czech Republic) were selected. Several techniques were used for their identification (analysis of local media, questionnaire survey, semi-structured interview). In this manner, it was possible to acquire a number of local actors from the public, private and non-profit sectors. Firstly, leaders in municipal development, whose position was examined by employing several approaches (positional, reputational and problem), were detected, and then social networks were analysed. The content transmitted within the networks, with an emphasis on social capital - a theme closely related to this issue - was also observed.
\end{abstract}

Keywords: actor, leader, social networks, social capital, development

Souhrn: Příspěvek se zabývá lokálními aktéry, kteří se aktivně zapojuji do rozvoje ve své obci. V problematice rozvoje venkova jsou zainteresovány subjekty různých úrovní a rozdílného postavení. Jejich role se však liší, stejně jako jejich pozice v sítích spolupracujících na rozvoji dané obce. Pro realizaci tohoto výzkumu byli vybráni aktivní obyvatelé v členských obcích místní akční skupiny Dolní Morava (rozkládající se na území Jihomoravského kraje České republiky). K jejich identifikaci bylo využito několik technik (analýza místních médií, dotazníkové šetření, polostrukturovaný rozhovor). Tímto způsobem byla získána řada lokálních aktérů pocházejících $z$ veřejného, soukromého i neziskového sektoru. Nejprve byly zjišt’ovány vůdčí osobnosti rozvoje obce, jejichž postavení bylo zkoumáno několika prístupy (pozičním, reputačním a problémovým), následně i analýzou sociálních sítí. $V$ rámci níž byl také sledován obsah přenášený uvnitř sítí s dưrazem na sociální kapitál, který je s touto problematikou těsně spjat.

Klíčová slova: aktér, vưdce, sociální sítě, sociální kapitál, rozvoj

\title{
1. Introduction
}

The development of rural areas affects a range of actors across sectors. Actors coming from outside influence the conditions of development. The role of internal actors at the lowest, local level is significant. Therefore, this article will address the local level and individual actors who are active. To achieve common goals in the development of their community, they are grouped into clusters of various types, which are internally connected links forming a social network. Their position within this structure is very important, as is the inclusion itself. Actors (or the nodes from the perspective of social networks) who have a special position in the network, having certain personality characteristics, can influence the entire network and its characteristics. These personalities will be discussed later in this article.

This research of these active actors examined the area situated to the southeast of the Czech Republic, near the border with the Slovak Republic. Specifically, there are 18 member municipalities of the Dolní Morava Local Action Group. Across this area are reflected viable characteristics, in particular, the focus on viticulture, traditions, folklore, and with it also a certain degree of pride, which can be called patriotism. The identity of this area is particularly strongly manifested. 
The LAG's position within the Czech Republic

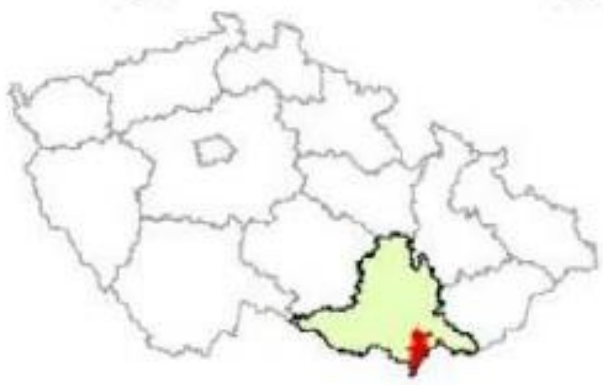

The LAG's position within the region

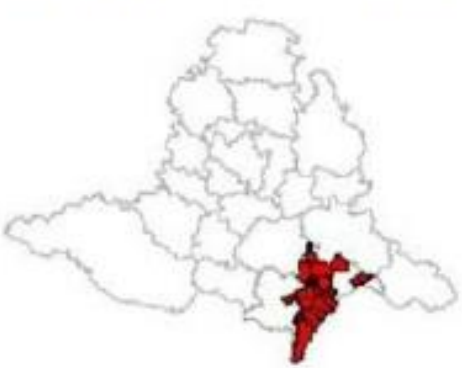

\section{LAG Dolní Morava}

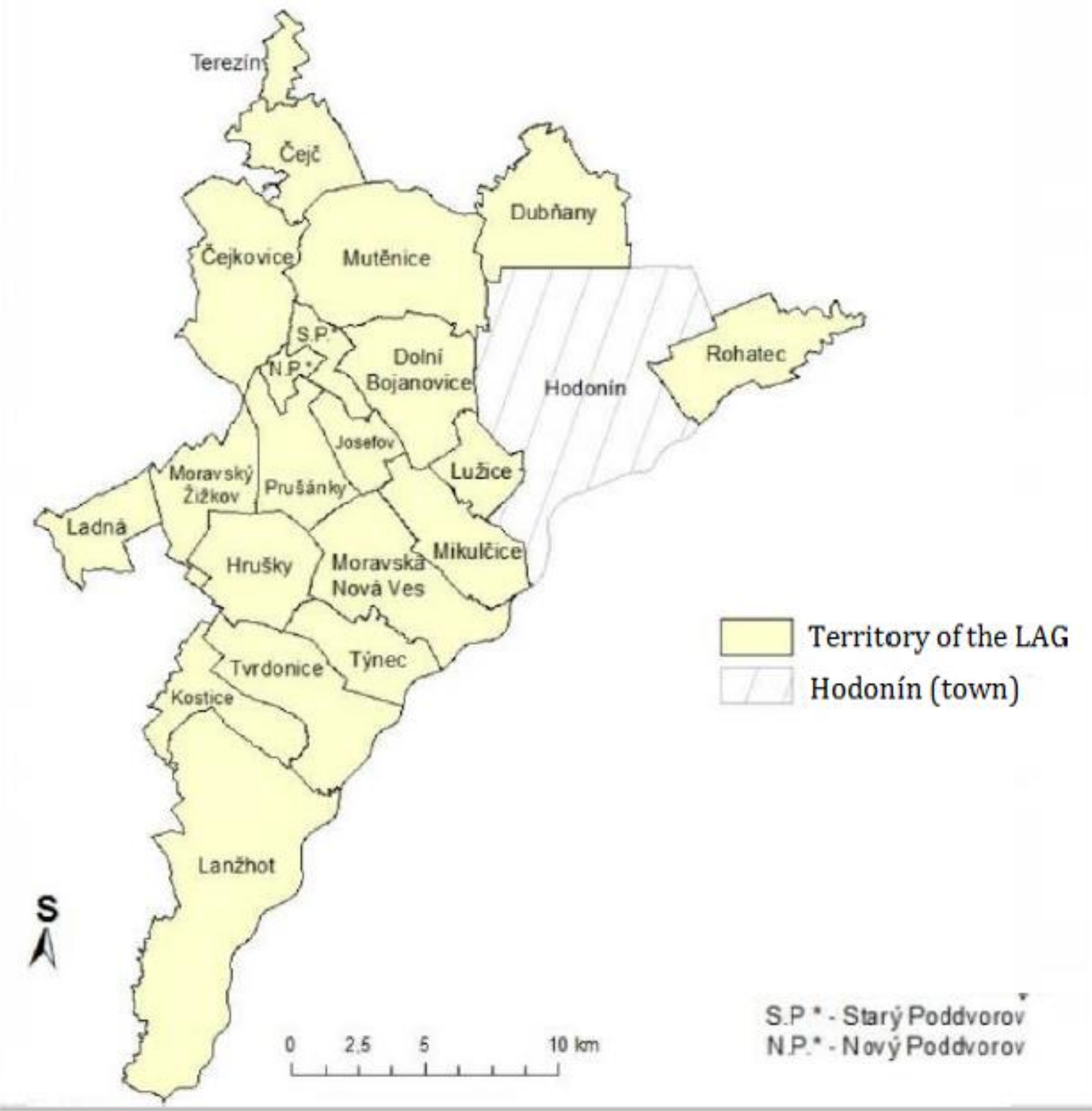

Fig 1. Location of the examined municipalities. Source: LAG Dolni Morava (2014) 


\section{Theoretical background}

In rural development, there are certain social networks formed, according to the concept of Izquierde and Hanneman (2006). A set of actors is interconnected through relationships or bonds. The strength of this link depends on the confidence, as well as on the amount of time, emotional certainty and mutual services among the actors (Granovetter, 1973). Through them, information is disseminated, actors are influenced, and links of a different nature are formed. These links enable effective participation and cooperation (Vajdová et al., 2010). These networks of contacts and close ties among actors enhance the ability of communities to mobilise resources and capacities, thus enabling a more flexible response to changes in the surroundings. They are therefore considered as a key factor in development (Cannarella, Piccioni, 2008), a prerequisite for creating a cooperative environment, characterised by a high degree of cooperation (Beugelsdijk, Schaik, 2005). Their next function involves serving as an access to information, as demonstrated by Granovetter (1973) in his diffusion model. Information is therefore another source of local development (Callois, Aubert, 2007; Čermák, Vobecká, 2011). Its diversified version is bridging linkages (Fromhold-Eisebith, 2004). It is clear that the function of networks is, as Callois and Aubert (2007) assert, to disturb distances and to connect nodes or actors to each other. It is also a tool to exploit the potential of social relations in the event of an emergency or the accumulation of power. Analysing networks makes it possible to point out the importance of the arrangement of informal groupings (Buštíková 1999; Degenne, Forse, 1994), since the focus is more on the relationships among actors than on the actors themselves (Hanneman, Riddle, 2005). Another way to look at the analysis of social networks is related to issues of power and knowledge. The power of an actor depends on the size of the network he can use to support himself. The ability to enforce depends on how well the networks are capable of mobilising their supporters. Thus, it is possible to look at different social phenomena and thereby give them a power dimension (Konopásek, 1996).

From the perspective of this article, it is the social network that allows access to harmonising the various actors so as to develop mutual cooperation that overcomes the problems of rural areas. For this reason, some authors (Edwards et al., 2001; Binek, Chabičovská, 2006) consider it as a key tool for rural development. Due to the specific rural environment, Constandse and Hofstee (1964) and also Pělucha et al. (2012) believe that the changes associated with development are accepted entirely by the local authority. Some of them consider themselves to be representatives of local government (Binek et al., 2009). As Chromý et al. maintain (2011), the promotion of active subjects who are willing to participate in community life and to enter into collaborative networks is most important. Cooperation, but also interaction and information exchange are important prerequisites for success. A combination of these elements leads to applying a participatory or bottom-up approach (Ray, 1997, 2001). This is an endogenous approach, focused on the activation of local residents and their involvement in the development of the site. This approach is a shift away from sector-oriented regional development to territoriallyfocused development (Barca, 2009; Furmankiewicz et al., 2010). It entails a focus on a cohesive area (place-based approach) with boundaries that do not necessarily coincide with the administrative ones. (Maurel, 2008). According to Ray (1999), the term "territory" includes an effort to formulate the possibilities of the people in a region to act on the basis of a sense of belonging. In this way, new structures are targeted to exploit local capacities. They are rooted in the region, as well as creating the possibility of inviting actors from all sectors to address developmental issues (Furmankiewicz et al., 2010). The described local partnership should therefore operate in a sufficiently small, geographically, economically and socially homogenous territory (Čepelka, 2001).

Furthermore, significant social capital, which is a form of wealth, including contacts and acquaintances, can be utilised (Šafr, Sedláčková, 2006). Its components are, according to Stachová (2008), social networks, voluntary associations of citizens, trust and reciprocity. It has a positive impact on local development by increasing citizens' engagement, promoting identity and belonging, as well as influencing social networks of development actors that transfer information among themselves (Stachová et al., 2009; Večerník, 1998). However, social capital is not always socially beneficial. A certain part of it, called bundling capital, serves, on one hand, to maintain close links within a group, including individuals with similar characteristics. On 
the other hand, it excludes dissimilar individuals. Therefore, Granovetter (1973) points out the danger of closure and exclusivity of individual groups that may abuse this position to their advantage. Another kind of social capital - bridging capital - is an important aspect of building citizens' cohesion, because it creates tolerant attitudes towards strangers and limits prejudices among groups. Linking the capital and linking actors across sectors allows for the efficient use of resources and the exchange of information (Stachová et al., 2009).

By analysing social capital, it is possible to determine the strength of the connection between the inhabitants of a given territory and its development (Faltová Leitmanová, 2012). One positive factor in a rural community is the higher frequency of contacts that confirms mutual trust not only within the group but also among citizens and self-government. Supporting self-government and its decisions by citizens makes it possible to implement unusual solutions to local problems (Fukuyama, 1999). On the contrary, a lack of time affects the social interactions of rural inhabitants (Putnam et al., 1993). For all forms of cooperation, there is a clear need of a mechanism to ensure effective coordination (Ambrosio-Albalá, Bastiaensen, 2010).

The issue of local leadership appears in this context. There are two types of structures. According to Bonjan and Olson (1964), this is characterised by a formal and informal power in local communities. This concept is a closed group of local elites - informal authorities or politicians influenced by voters. In fact, there are also leaders of a mixed character. Following these findings, leadership in communities can be divided into two directions - pluralism and elite theory. There are several personalities considered as being rural leaders throughout history. Most often, the Mayor, the priest and the teacher were named, and later, officials of unified agricultural cooperatives (in the Czech Republic). Some of these have been unable to maintain their positions, as there has been a shift in perceived importance. For example, a Mayor endowed with legitimate power represents natural authority. A number of authors write about this position. These include Illner (1996) Perlín (2000) and Jančák et al. (2010). In addition, it should be noted that bearing the role of Mayor directly determines leadership by simply equipping him with resources that other actors do not have. Wilkinson (1991) presents another viewpoint, which does not expect leaders to be members of the local government. He highlights the role of informal actors, rooted in civil society, with the aim of creating a community. Natural authority therefore does not necessarily hold an official position, but its initiative and energy can affect the whole group. Similarly, the important role of informal enthusiasts, especially in smaller municipalities, is stressed in the research by Chromý et al. (2011).

Not only formal and informal leaders shape rural development and participate in it. Residents, users, organisations and institutions, whose interests and preferences may conflict with each other, are also involved (Granovetter, 1973). Differences among actors are at the level of action. However, this research also deals with local actors directly implementing development activities in the sector. Nevertheless, it is necessary to achieve some synergies in the relationship among the actors involved in this activity and those implementing development frameworks. (Binek et al., 2009; Knickel, Renting, 2000)

\section{Aims and Methods}

The main objective is to identify the most important actors in the social networks of individual municipalities (to compare the findings in several ways), as well as to explore the content flowing through the links among actors (nodes in social networks).

In order to identify important actors for further research, it was necessary to analyse the local media. For this, printed sources (newsletters, magazines) and Internet resources (municipalities' websites and others) were used. Subjects thus designated were subsequently approached to participate in the questionnaire survey, which was used by approximately 65 percent of the respondents. The snowball method was also used. This involved respondents recommending other active individuals, which in many cases already confirmed the position of selected subjects of research or increased the number of subjects.

The fundamental technique used was a semi-structured interview, conducted with every Mayor in a total of 18 municipalities and approximately 30 other actors who had proven to be significant 
in terms of position in the network. The outputs of these interviews were systematically collected and subsequently analysed to "emerge what is important in this area" (Strauss, Corbin, 1999: 14).

In this way, data were obtained to form an adjacency matrix, or 1-modal, which is always square. This means the number of columns is equal to the number of rows - both rows and columns represent the same group of units. In this way, it was possible to capture the relationships among the units themselves.

In this context, the research is based on the assumption that individual groups of respondents will look at the facts examined differently, because they have various social roles. Therefore, to achieve a higher degree of objectivity of the results associated with their validity and reliability, it was appropriate to include these groups of respondents in the research. All parts of this research were carried out from September 2017 until the end of June 2018.

The last part of this research focused on analysing social networks through the UCINET in order to obtain the following characteristics of actors in social networks:

- Network core identification - using the Core/Periphery procedure to obtain network nodes.

- Centrality - monitors the number of direct entity links to other network actors (basically measuring network activity).

- Closeness - the expression of the distance (path length) between different peaks of the graph; it also indicates the expected delivery time of any information transmitted over the network.

- Betweenness - as a numerical expression of bridging and bonding, it expresses the ratio of the shortest paths between all possible pairs of nodes on which the given node lies to all others.

Social Network Analysis was applied according to John Scott's concept as "a set of methods for the analysis of social structures," (Scott, 2000: 38), rather than a specific theory.

\section{Empirical part}

Personalities, who can be described as leaders or powerhouses of development in municipalities, were investigated using several approaches. In the first stage, a positional approach was applied by analysing local media, where individuals with significant community influence were identified as a result of their position in a particular organisation. The employment of this method allowed for the discovery of representatives of self-government as well as representatives of individual associations, private organisations and, in some cases, those of a non-profit character (e.g. Primary School principals). While it was not possible to reveal their real activity in the development of the municipality, the results from this part served for further processing and comparison.

A questionnaire was also used to identify community leaders in municipalities. This served as a way of identifying who fulfils these functions, thanks to active rural residents who are also included in social development networks. The reputation approach identified the Mayor's main position, followed by the Council or Board. The specific results for each municipality are shown in Figure 2.

In the survey, the context of the problem approach was addressed in one question. This resulted in the confirmation of the position of Mayor in more than 55 percent of responses, while the Council or Municipal Board were identified in 27 percent of responses. Other subjects were selected with less frequency. 


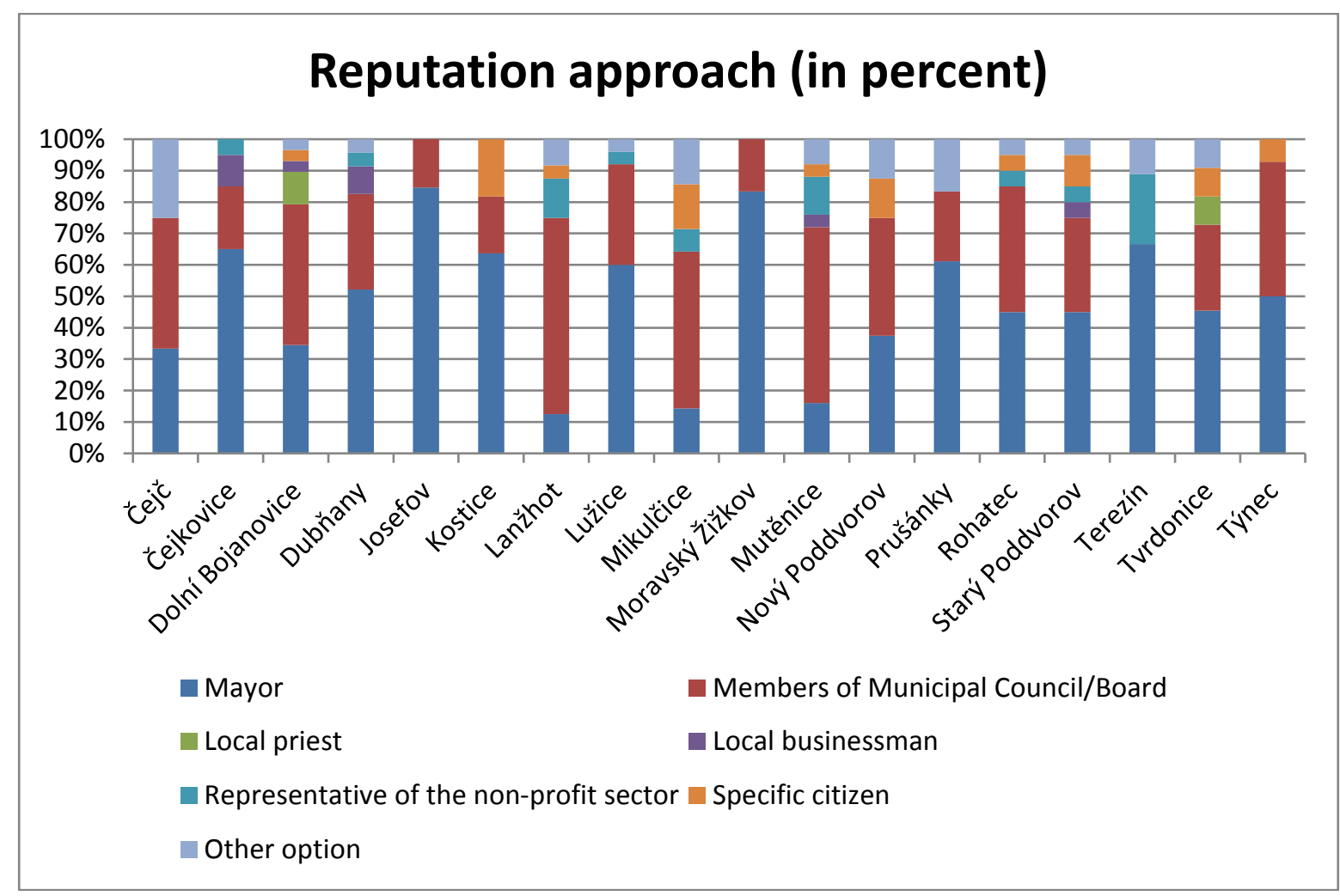

Fig 2. Local leader according to respondents' answers.

In their interviews, mayors often referred to themselves as key actors (i.e., they are aware of the importance of their position and also the responsibilities arising from it), and they were usually supplied by councils or associations. The Mayor, although only one person, has a very important function and exists in all municipalities (unlike the Board). Moreover, his election points to a significant position in the village. As the previous sections of the research have shown, the Mayor occupies top position among all active individuals in the village. One of the reasons is his job, but also his own fervour - that will probably be the reason why citizens chose him. As Bernard (2012) and McDermott (1998) state, voters at this level make their choice based on their preferred personality characteristics. Moreover, in most cases these are based on experience, as almost all mayors of the investigated municipalities have been re-elected.

As it may be seen, it follows that the above-mentioned parts of the survey are consistent with each other, but it still has not been determined how important the position of Mayor really is, or whether it is merely a stereotype. Therefore, a social network analysis was carried out. Using the data obtained from interviews and questionnaire surveys, an adjacency matrix was created for each community. Subsequently, important features relating to the position of the network actors were identified. Firstly, there were entities in each village that have denser relationships with each other than the rest of the network. This is the core of the network that was determined using the Core - Periphery procedure in the Ucinet program. This concerned a variety of subjects in each municipality (in the range of 3-13 subjects). It can be argued that this is an indicator of the importance of individual actors. Entities designated by this process play the most important role in the network.

For all municipalities, the above-mentioned procedure resulted in a high proportion of subjects belonging to the government. It was always the Mayor, then most often the Council and often the Board. Not every village (due to its size) has a Board set up, so that there is a larger proportion of the Council, and thus this larger share of the Council. This is manifested by the fact that the Board is composed of Members of the Council (involving more people than the Board). This evaluation points out the important position of public sector actors and representatives of local government. Furthermore, clubs of various orientations were often also included, mainly volunteer fire brigades, folklore or sports groupings. These data are listed in the Table below - marked by $\mathrm{X}$. 
Tab 1. Actors in Municipalities.

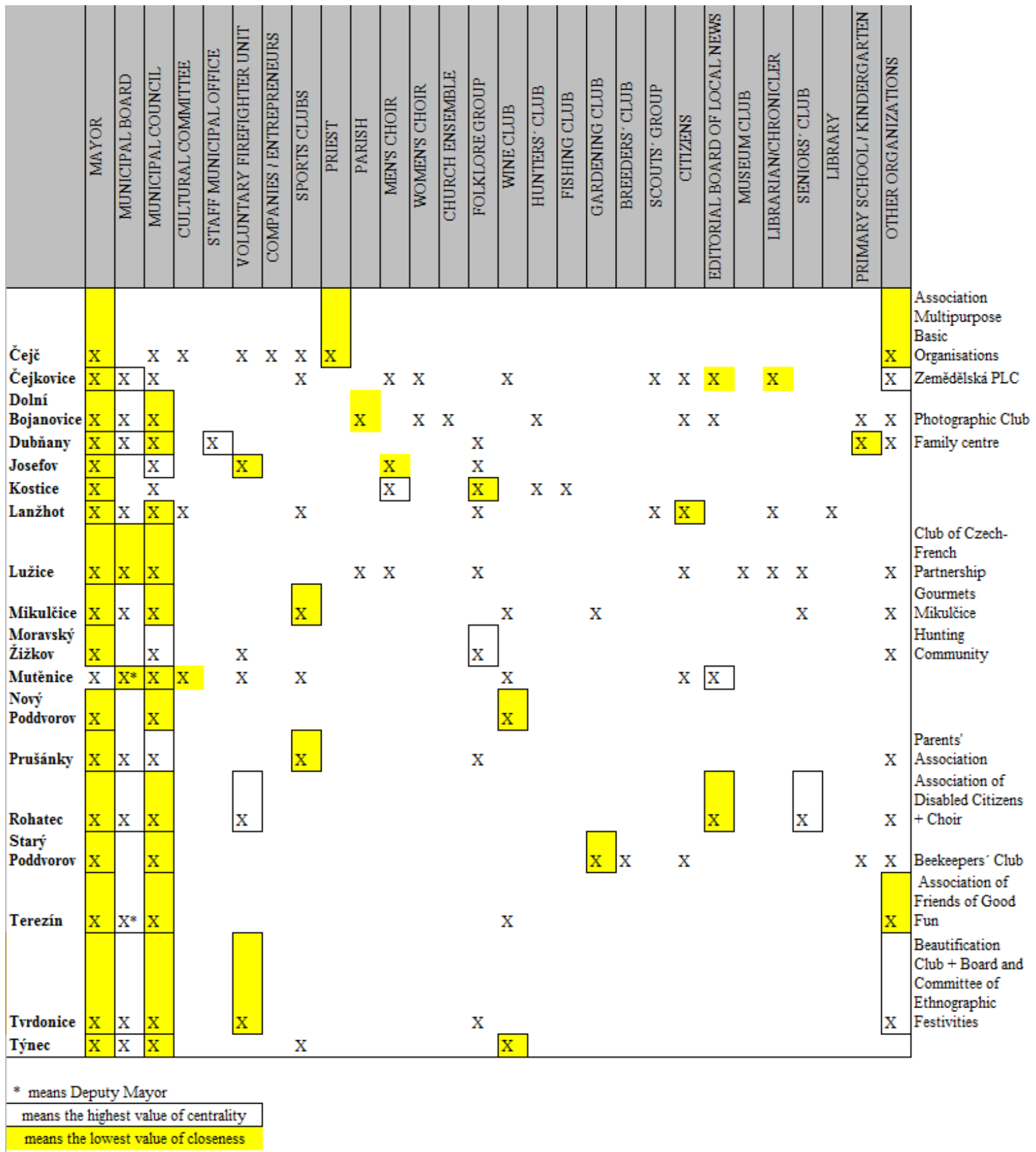

The value of centrality and closeness was used to discern a more detailed identification of the crucial actors in the network. This enabled actors with larger numbers of contacts (for the centrality values) to be chosen. These actors occupy positions in which they can exert their influence on others in the network and play important roles in the information distribution process. They can provide information, be asked for it, or also convey information from outside the network. The subjects thus identified were bordered in the Table $1^{2}$. They are overall representatives of self-government, with the Mayor occupying the most significant position, followed by the Council. Using the closeness factor, the average distance from other nodes in the network was analysed. Their location is also related to information and, above all, access to it, but also to the time they need to be distributed within the network. Subjects with the lowest value, highlighted in yellow,

\footnotetext{
${ }^{2}$ Initially, it was planned always to use three subjects with the highest value, and, after the evaluation proceeded, to add other actors with similarly high values.
} 
were identified for closeness. There is also a visible predominance of self-government (especially concerning the Mayor) over other actors. However, their frequency was significantly lower. More often, there are associations with a narrower focus (hunters, beekeepers, theatrical associations), while companies and entrepreneurs also appear.

By examining the positions in the network, the most important actors in the communities were identified. Synchronisation is shown in the Table 1.

The Table shows the central role clearly held by the local public administration. This fact was confirmed during the interviews. Position personalities in the network will probably be an important prerequisite for election. Representatives of the municipality are in contact with other important actors and, in addition, have the necessary amount of information. This information is both a prerequisite for their location in the network and the consequence of this position. (For example, the Mayor participates in meetings, so he has rather good access to information). In addition, representatives are generally elected in rural areas according to certain personality traits, such as how publicly known they are, and based on some of their activities. Often, they are people engaged in a specific area, or those representing an association. Even the Mayor is in closer contact with specific groups or individuals, with whom he then engages when required (e.g., AMBO for Čejč or Josefov and the voluntary firefighter unit). In many cases, the Mayor is a member, often even a formal representative. It could therefore be said that there is a stronger link among the entities that have been identified as significant by all three characteristics. Mayors are marked in all municipalities, the only exception being the municipality of Mutěnice, where the Deputy Mayor is marked as such. In addition, the Council is also selected in 12 municipalities. Furthermore, a particular association is marked 10 times.

The last examined feature of individuals in the networks was betweenness, used to find nodes that function as gatekeepers, through which the quantity of commodities flows. These commodities include not only information again, but also activities or any other content of the network. In other words, the expression of bridging and bonding is evident. The node thus obtained will associate different clusters of actors and serve to show network interconnections. Its absence would entail the risk of disconnecting the network and interrupting the networking of entities. The results of this part were in agreement with the previous findings. Betweenness also pointed out the prominent position of Mayor (in a total of 17 municipalities). The Municipal Council (in 12 municipalities) was also often referred to, and the volunteer fire brigade repeatedly appeared. In other cases, the subject (most often an association) occurred less often. In principle, these facts are consistent with previous results.

The Mayor is therefore intended as a key gatekeeper, who significantly brings together local communities and various groups of actors. Initial leaders such as priests and teachers appeared only sporadically; they were usually part of some of the institutions (parish, school).

Identified leaders were also asked about the content of the networks in which they play a part. The role of confidence was firstly emphasised. Almost all mayors, with the exception of four, mentioned its importance. In the other three cases, it played a slightly smaller role, though even here it was considered as important. The last Mayor claimed that confidence was a factor at the intermunicipal cooperation level, but noted its absence on the local level. This context often emphasised the activities of associations (mostly volunteer firefighters).

These findings are not surprising. Due to the size of the municipalities, cooperation between actors is largely informal, sometimes even on family basis (the degree of formalism proved to be inversely proportional to the size of the municipality; in smaller municipalities, stronger ties prevail). Expressed confidence thus indicates the amount of social capital occurring in social networks. Many mayors introduced the experience contained in social networks, because they had just been using the experience of the previous activity (cooperation). They are also part of social capital as a basis for creating mutual trust. As reported by Vajdová (2010), confidence is created through repeated experience (no declaration). Other identified contents of social networks are communication and activity. The flow of information is essential for the correct settings of cooperation, especially in order to achieve a common goal for citizens of informativeness related to satisfaction. Networks therefore have a two-way exchange of information and activities. In most cases, this concerns a selfless and voluntary activity. Funds are mainly allotted to clubs by 
the municipalities and usually in the form of subsidies for their operations. The management of municipalities often provides facilities and technical equipment. Conversely, clubs are willing to participate in activities organised by municipalities by providing a part of the organisation, offering their own products or other desired activities.

The bridging capital linking individual sectors to each other has also been shown to be the content of networks, the most important link being between the non-profit sector, represented mainly by associations, and the public sector (community management).

From the above findings, social capital seems to be at a fairly good level. More than half of the mayors express satisfaction with the cooperation. Furthermore, about one-third of these mayors evaluate it as neutral, because they see room for improvement. However, there are also individuals who evaluate this area negatively. They find problems of a rather individual character (in selected individuals), especially in communication. This is why the socialisation effect of associations that integrate citizens is emphasised.

\section{Conclusion and discussion}

This paper deals with the determination of significant people at the local level. Several techniques were used for their determination. Content analysis was the first to be applied, which, despite its demanding nature, brought about a relatively good basis for active individuals in municipalities. Because only individuals were detected, but not their activities or positions in the network, it was necessary to supplement this information. This was done through interviews and a questionnaire survey using the snowball method, which was able to reveal actors especially among informal personalities. Distortion was eliminated by using a diverse sample of subjects examined across sectors.

Using social network analysis, it was possible to examine actors depending on their positions in the network. Above all, the individuals that this concerned have larger quantities of social capital, have more contacts and are endowed with greater power or influence on other players. Their role is also essential in terms of information mediation. Therefore, their presence in the network is irreplaceable, because they are able to induce a specific activity and a favourable effect on the characteristics of the network, including its extension. Not only this analysis, but also the use of individual approaches through questionnaire surveys and semi-structured interviews, confirmed the prominent position of Mayor. In addition, other important actors in the development of municipalities were identified, and these were Councils and some associations. Usually, in each municipality, there is one particularly beneficial association that engages in a relatively wide range of activities.

In this way, the mayors of municipalities were identified as leaders of local activities. Their status is formal (they are endowed with legitimate powers), although some previously held other roles in the life of the community, which finally coalesced. It is therefore possible to consider their mixed nature. Their position was also confirmed during the detection of betweenness. Mayors also act as gatekeepers, coherent network nodes. Their absence could lead to the elimination of the cohesion, even to the disconnection of the network. In this sense, they act as bridges - they connect groups as well as extend information. The role of Mayor is thus irreplaceable in the rural community. He is the main powerhouse of development and also a local leader. This reflects the strong position of mayors, who have this information and receive it from various meetings and consultations, not only from their duties, but also from their own activities and interests. They are therefore very close to the sources of information that they spread, in the sense of developing a managed territory. Furthermore, the important position of the Council was found, alternatively also the Board. This suggests that local public administration is the driving force for the development of municipalities in the monitored area. An important collaborator is, in most cases, an association (club) - most often a voluntary fire brigade. In terms of development, the inclusion of these leaders in the network is very important, because they have more social capital, they have more contacts, they have more power or influence on other actors. They are also an important source and mediator of information. This has a positive effect on some network characteristics. 
Another part of the research involved the questioning of these important personalities on the content of social networks. Above all, confidence was a factor, and it is based on experience from previous interactions, as well as on information that is also reflected in the above-mentioned trust. To some extent, there are also funds and activities of various types, depending on the previous parts of the network (again, especially on trust). Social capital has thus been found at quite high levels, as witnessed by the evaluation of cooperation from the perspective of municipal mayors. Its individual types and parts contribute significantly to achieving development goals.

Rural development is applied in accordance with the Furmankiewicz et al. (2010) model in this cohesive area that suits both size and homogeneity, so that we can speak of a place-based approach. Actors are rooted in their networks of contacts, also working across sectors, although leaders (central actors) dominate public administrations. A very substantial part of development is activating local actors, as well as cooperation that enables development goals to be achieved more effectively, including the inclusion of individual parts of social capital.

\section{Academic references}

[1] Ambrosio-Albalá, M. \& Bastiaensen, J. (2010). The new territorial paradigm of rural development: Theoretical foundations from systems and institutional theories. University of Antwerp: Institute of development policy and management.

[2] Barca, F. (2009). An Agenda for a Reformed Cohesion Policy. A Place-Based Approach to Meeting European Union Challenges and Expectations. Independent Report.

[3] Bernard, J. (2012). Individuální charakteristiky kandidátů ve volbách do zastupitelstev obcí a jejich vliv na volební výsledky. Sociologický časopis 48(4), 613-640.

[4] Beugelsdijk, S. \& Schaik, T. (2005). Differences in social capital between 54 Western European regions. Regional Studies 39(8), 1053-1064. DOI: 10.1080/00343400500328040.

[5] Binek, J. \& Chabičovská, K. (2006). Význam spolupráce ve veřejné správě. Zdokonalování veřejné správy a samosprávy ČR. Brno: Konvoj.

[6] Binek, J. et al. (2009). Synergie ve venkovském prostoru. Aktéři a nástroje rozvoje venkova. Brno: GaREP Publishing.

[7] Bonjean, Ch. M. \& Olson, D. M. (1964). Community leadership: directions of research. Administrative Science Quarterly 9(3), 278-300. DOI: 10.2307/2391442.

[8] Buštíková, L. (1999). Analýza sociálních sítí. Sociologický časopis 35(2), 193-206.

[9] Callois, J. M. \& Aubert, F. (2007). Towards indicators of social capital for regional development issues: The case of French rural areas. Regional Studies 41(6), 809-821. DOI: 10.1080/00343400601142720.

[10] Cannarella, C. \& Piccioni, V. (2008). Innovation diffusion and architecture and dynamics of local territorial network. Trames Journal of the Humanities and Social Sciences 12(2), 215237. DOI: $10.3176 /$ tr.2008.2.06.

[11] Constandse, A. K. \& Hofstee, E. W. (1964). Rural Sociology in Action. [FAO Agricultural Development Paper]. Rome: Food and Agriculture Organisation of the United Nations.

[12] Čepelka, O. (2001). Iniciativa Evropské unie LEADER pro rozvoj venkova. Ministerstvo pro místní rozvoj ČR. Praha.

[13] Čermák, D. \& Vobecká, J. (2011). Spolupráce, partnerství a participace v místní veřejné správě: Význam, praxe, príslib. Praha: Sociologické nakladatelství (SLON).

[14] Degenne, A. \& Forsé, M. (1994). Les réseaux sociaux. Une analyse structurale en sociologie. Paris: Armand Colin. 
[15] Edwards, B., Goodwin, M., Pemberton, S. \& Woods, M. (2001). Partnerships, power, and scale in rural governance. Environment and Planning C: Government and Policy 19(2), 289 310. DOI: $10.1068 / \mathrm{c} 12 \mathrm{~m}$.

[16] Faltová Leitmanová, I. (2012). Venkov jako místo pro žití. Praha: Wolters Kluwer.

[17] Fromhold-Eisebith, M. (2004). Innovative Milieu and Social Capital - Complementary or Redundant Concepts of Collaboration-based Regional Development? European Planning Studies 12(6), 747-765. DOI: 10.1080/0965431042000251846.

[18] Fukuyama, F. (1999). Social Capital and Civil Society [IMF working paper]. Washington: International Monetary Fund.

[19] Furmankiewicz, M., Thompson, N. \& Zielińska, M. (2010). Area-based partnerships in rural Poland: The post-accession experience. Journal of Rural Studies 26(1), 52-61. DOI: 10.1016/j.jurstud.2009.05.001.

[20] Granovetter, M. S. (1973). The Strenght of Weak Ties. American Journal of Sociology 786), 1360-1380.

[21] Hanneman, R. A. \& Riddle, M. (2005). Introduction to social network methods. Riverside, CA: University of California.

[22] Chromý, P., Jančák, V., Marada, M. \& Havlíček, T. (2011). Venkov - žitý prostor: Regionální diferenciace percepce venkova představiteli venkovských obcí v Česku. Geografie 116(1), 23-45.

[23] Illner, M. (1996). K otázce reprezentativnosti místních zastupitelstev. In: Hampl, M., Geografická organizace společnosti a transformační procesy v České republice (pp. 343351). Praha: Univerzita Karlova.

[24] Izquierdo, L. R. \& Hanneman, R. A. (2006). Introduction to the Formal Analysis of Social Networks Using Mathematica. Published in digital form at http://www.luis.izquierdo.name. University of Búrgos.

[25] Jančák, V., Chromý, P., Marada, M., Havlíček, T. \& Vondráčková, P. (2010). Social capital as a factor in the development of peripheral areas: an analysis of selected components of social capital in Czechia's typologically different peripheries. Geografie 115(2), 207-222.

[26] Knickel, K. \& Renting, H. (2000). Methodological and conceptual issues in the study of multifunctionality and rural development. Sociologia Ruralis 40(4), 512-528. DOI: 10.1111/1467-9523.00164.

[27] Konopásek, Z. (1996). Sociologie jako power play. Sociológia 28(2), 99-125.

[28] Maurel, M.-C. (2008). Local development stakeholders and the European model: Learning the LEADER approach in the new member states. Czech Sociological Review 44, 511-529.

[29] McDermott, M. L. (1998). Race and gender cues in low-information elections. Political Research Quarterly 51(4), 895-918.

[30] Pělucha, M. et al. (2012). Venkov na prahu 21. století: venkov a jeho rozvoj na přelomu milénia, územní dopady znalostní ekonomiky na venkov, souvislosti vztahů města a venkova $\checkmark$ globalizované ekonomice. Praha: Alfa nakladatelství.

[31] Perlín, R. (2000). Představitelé veřejné správy jako aktéři lokálního rozvoje. In: Kubeš, J., ed., Problémy stabilizace venkovského osidlení ČR (pp. 133-151). České Budějovice: Jihočeská univerzita.

[32] Putnam, R. D., Leonardi, R. J. \& Nanetti, J. Y. (1993). Making democracy work: Civic traditions in modern Italy. Princeton, NJ: Princeton University Press.

[33] Ray, Ch. (1997). Towards a theory of the dialectic of local rural development within the European Union. Sociologia Ruralis 37(3), 345-362. DOI: 10.1111/j.14679523.1997.tb00055.x. 
[34] Ray, Ch. (1999). Towards a meta-framework of endogenous development: repertoires, paths, democracy and rights. Sociologia Ruralis. 39(4), 521-537. DOI: 10.1111/14679523.00122.

[35] Ray, Ch. (2001). Transnational co-operation between rural areas: elements of political economy of EU rural development. Sociologia Ruralis 41(3), 279-295. DOI: 10.1111/14679523.00183.

[36] Scott, J. (2000). Social Network Analysis. London: Sage Publications.

[37] Stachová, J. (2008). Občanská společnost v regionech České republiky. Praha: Sociologický ústav AV ČR.

[38] Stachová, J., Bernard, J. \& Čermák, D. (2009). Sociální kapitál v České republice a v mezinárodním srovnání. Praha: Sociologický ústav AV ČR.

[39] Strauss, A. \& Corbinová, J. (1999). Základy kvalitativního výzkumu. Brno: Sdružení podané ruce.

[40] Šafr, J. \& Sedláčková, M. (2006). Sociální kapitál: koncepty, teorie a metody měření. Praha: Sociologický ústav AV ČR.

[41] Vajdová, Z. (2010). Starostovo a starostčino dilema aneb sociální kapitál na vsi a na městečku. In Kostelecký, J., Lebeda, T., Maříková, H. \& Škodová, M., eds., Jaká je naše společnost? Otázky, které si často klademe (pp. 261-273). Praha: Sociologické nakladatelství (SLON).

[42] Vajdová, Z., Bernard, J., Stachová, J. \& Čermák, D. (2010). Sít' institucionálních aktérů rozvoje malého města. Sociologický časopis 46(2), 281-299.

[43] Večerník, J. (1998). Občan a tržní ekonomika: př́imy, nerovnost a politické postoje $v$ české společnosti. Praha: Nakladatelství Lidové noviny.

[44] Wilkinson, K. P. (1991). The Community in rural America. Westport: Greenwood Publishing.

Other sources

[45] LAG Dolní Morava o.s. (2014). Integrovaná strategie komunitně vedeného místního rozvoje (SCLLD) na období 2014-2020. 